\title{
DOMESTIC HEATING AND THERMAL INSULATION
}

$\mathrm{D}^{\prime}$ IGEST 133 of the Building Research Station, entitled "Domestic Heating and Thermal Insulation" (Pp. 7. London : H.M. Stationery Office, 1960. 4d.), brings together the essentials needed to guide the choice of the standard and methods of heating from among the many systems that are available. In choosing a domestic heating system the decisive questions are : What standard of heating is required ? How much will it cost to run? Convenience in operation and the form of heat distribution preferred are also important.

Broadly, the systems of domestic heating can be divided into three main categories : (1) Full house warming. (2) Partial heating, that is, the full heating of two or three rooms from a central heat-source, with the remainder of the house heated as required by gas or electric fires : or the background warming of the whole house to a uniform temperature lower than that obtained by category (1) together with 'topping up' in individual rooms as required. (3) Heating limited to individual appliances in one or two of the main living rooms.

The main differences in the three standards of heating are in the scope of the heating service. In the full house-warming systems and background heating systems, for example, comfort is enhanced by the fact that the house is uniformly warm ; such systems are essential for the open-house plan. By contrast, systems using separate appliances, for example, open fires, in a limited number of rooms give a lessuniform standard of comfort.

The standards covered by these three categories can be characterized broadly in terms of difference between the average outdoor temperature over the whole heating season and the average indoor temperatures they provide.

Assuming an average seasonal outdoor temperature of $43^{\circ} \mathrm{F}$., a temperature difference of $18^{\circ} \mathrm{F}$., averaged over $24 \mathrm{hr}$., can be taken as representative of full house warming, $13^{\circ} \mathrm{F}$. for partial central heating systems and $11^{\circ} \mathrm{F}$. or less for the third category.
The smaller temperature difference between the medium and low standards of heating may be explained by the fact that even in dwellings where the bedrooms are unheated some stray heat is received from the heated part of the house. These average temperature differences can help in estimating seasonal fuel requirements and, therefore, running costs. They are not, however, appropriate for estimating maximum heat demands and hence the size of the heating plant; these have to be calculated from a maximum temperature difference between indoors and outdoors.

For a fair comparison of capital costs of various domestic heating systems, account should be taken of any building costs incidental to the heating installation, such as those of brick flues and fuel stores, or, conversely, the saving effected if these items are not required. For example, in a system comprising one open fire with back boiler, electric immersion heater for summer use and two electric fires, the cost of a chimney breast and flue and a fuel store for the open fire is about 25 per cent of the total cost of the installations. Broadly, the capital costs of the three categories of heating are in the same order as the standard of heating attained, but there may be some overlapping.

The seasonal heat loss for a particular dwelling will depend to some extent on the overall floor area, on the grade of insulation, the standard of heating, the ventilation-rate and the length of the heating season.

To estimate the seasonal fuel requirements the seasonal loss of heat should be divided by the calorific value of the fuel multiplied by the 'house efficiency' of the heating system.

Other points affecting the choice of a heating system are convenience in operation and the form of heat distribution. The size and number of heating appliances required for a particular heat service depend mainly on the maximum heat demand during a cold spell.

\section{POPULATION TRENDS AMONG HAWKS AND OWLS IN ILLINOIS}

$\mathrm{D}^{\mathrm{A}}$ ATA hawks and owls in Illinois, as reported in the Christmas counts sponsored by the National Audubon Society and its parent organizations, have been analysed by Richard R. Graber and Jack S. Golden to determine population trends for the years 1903-55 (Biological Notes, No. 41. Dept. Registration and Education, State of Illinois).

Even though most of northern and central Illinois offered a fairly uniform habitat of cultivated farm land with relatively little forest, the distribution of raptors was not uniform, and raptor populations varied considerably even within relatively small areas. Highest concentration of raptors was in the southern part of the State. Through the years a given locality, in relation to other localities, has tended to show a consistent rank with regard to the density of its raptor populations.

Analysis of frequency of occurrence for all species of raptors in the period 1903-55 was based on 527 censuses-103 in southern, 123 in eentral, and 301 in northern Illinois. This analysis shows the expected higher frequency of prairie-inhabiting species of raptors in central and northern Illinois and of woodland species in southern Illinois. Regardless of habitat, certain species, such as the sparrow hawk and the marsh hawk, were seen with increasing frequency from north to south, as though responsive to a temperature cline.

The combined data for all raptor species show that there has been a marked and consistent decline in winter raptor populations during the period 1903-55. Peaks representing years of high populations are lower in later years. Trends in raptor populations were deduced from birds per observer-hour, birds per party-hour, and birds per mile.

The records of individual species show that the rough-legged hawk has suffered the severest decline in numbers; the red-tailed hawk, the sparrow hawk 
and the barred owl also decreased. Marsh hawk and the red-shouldered hawk populations have not changed appreciably. The bald eagle has been increasing in numbers since the early 1940 's; but this is the only species for which a notable increase was shown. The records for many species are too incomplete to evaluate.

Because the decline in raptor populations is shown particularly among the less-wary species and those species that are most likely to be encountered by man, it is suggested that man may be directly responsible for the decline. This view is corroborated by the fact that many raptor band returns are from birds that were trapped or shot and also by the indication that a notably lethargic species, the rough-legged hawk, has suffered the severest decline.

The species of raptors, namely, Buteo spp., Circus spp. and Falco sparverius, which have been protected by law since 1919, were seen at least seven times as frequently as the previously unprotected accipiters and the great horned owl.

\section{SINGAPORE BOTANIC GARDENS}

\begin{abstract}
A
SPECIAL issue of the Gardens' Bulletin (17, Pt. $2 ; 1959$. 12.50 dollars. Obtainable from the Botanic Gardens, Singapore) has been issued to commemorate the hundredth anniversary of the founding of these well-known gardens. In fact, a botanic garden was established in Singapore soon after its founding in 1819 by Sir Stamford Raffles, nutmegs, cloves and cocoa being among the early introductions. This garden was closed after some years in a retrench ment of expenditure, but new gardens, the present ones, were established on a new 60-acre site towards the end of 1859 (see also Nature, 184, 1602; 1959).

Since then the gardens have been extended and amplified and for many years have been recognized as being among the most important tropical institutions of this kind, the more so as they are set in a region of very considerable agricultural importance and quite exceptional floristic interest. Virtually from the outset, the staff have paid attention to the needs of practical agriculture and horticulture as well as to systematic and other aspects of scientific botany usually associated with botanic gardens. This was exemplified in a remarkable degree by the work of Dr. H. N. Ridley, director of the Gardens during 1888-1912, who has not only been rightly named "the father of Malaya's rubber industry" but was also responsible, as an indefatigable field botanist, for vast accessions of new plants to the gardens and its horbarium. After his retirement, he produced his
\end{abstract}

five-volume work on the "Flora of the Malay Peninsula" (1922-25).

As several distinguished botanists have worked on the staff of the Singapore Botanic Gardens over the years, the output of work, often on plants of unusual scientific interest, has been both extensive and impressive. In the present commemorative volume (pp. 125-340) the reader will find much that is pertinent, informative and interesting. J. W. Purseglove has contributed a paper on the history, functions and contemporary work of the gardens; T. A. Russell has described the relationships between them and the Royal Botanic Gardens, Kew ; while H. J. Lam has written of Singapore and Leyden. Other authors deal with the contribution which work in the gardens has made to agriculture in the Malaysian region, and there are several papers of both general and special interest by well-known botanists ; for example, R. E. Holttum has written on his work on orchids, gingers and bamboos carried out in the gardens, and E. J. H. Corner has discussed the importance of the taxonomy of tropical plants in contemporary botany; and so on.

Perhaps the best way of indicating briefly the value of the present volume is simply to say that, for the general botanical reader, it affords an unusually interesting introduction to the many facets and fascinations of tropical botany.

\section{ROAD ACCIDENTS DURING CHRISTMAS 1959}

$\mathrm{T}$ WO factors stand out in the Road Research Laboratory report of the investigation of the 150 fatal road accidents in England and Wales during the Christmas period (December 24-27, 1959)--the bad weather conditions and the unusually high proportion of people involved in the accidents who had taken alcohol (Road Research Technical Paper. No. 49. Pp. iv +20 . Published for the Department of Scientific and Industrial Research by H.M. Stationery Office, 1960. 1s. 9d. net).

The investigation was carried out at the request of the Minister of Transport and shows that the number of fatalities per mile travelled by motorvehicles was high on each of the four days of the Christmas period when compared with the other days in December or with the year as a whole.

The factors usually associated with road accidents (such as vehicle defects, cross-roads, and skidding on wet roads) were present in the normal proportion.
The weather conditions were bad. Roads were dry for only 10 per cent of the accidents; in 73 per cent it was dark and wet; in 12 per cent it was daylight and wet; and in 5 per cent it was icy. The report states: "this weather would be expected to result in increased accident frequency but not to the extent that occurred".

In at least 56 per cent of the accidents one or more of the people involved had taken alcohol not long before the accident. The corresponding figure in a normal period is 18 per cent. The report concludes : "the bad weather of the Christmas period made travelling conditions difficult. The fact that many of the people involved in the accidents had been drinking beverages containing alcohol would be expected--in the light of previous research-to have made many of them less able than usual to deal adequately with the difficult conditions. Although other factors may have been involved, the combination of these two alonemight account for the high accident-rate over the period". 